\title{
Marine natural seaweed products as potential antiviral drugs against Bovine viral diarrhea virus
}

\author{
Ana Maria Viana Pinto, $,, 1,2$ José Paulo G. Leite, ${ }^{3}$ Wilton J. \\ Ferreira, ${ }^{4}$ Diana N. Cavalcanti, ${ }^{5}$ Roberto C. Villaça, ${ }^{5}$ Viveca \\ Giongo, ${ }^{2}$ Valéria L. Teixeira, ${ }^{4,5}$ Izabel Christina Nunes de \\ Palmer Paixão ${ }^{1,2}$
}

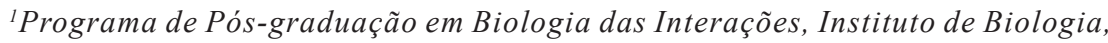
Universidade Federal Fluminense, Brazil,

${ }^{2}$ Departamento de Microbiologia e Parasitologia, Instituto Biomédico, Universidade Federal Fluminense, Brazil,

${ }^{3}$ Laboratório de Virologia Comparada, Instituto Oswaldo Cruz, Fundação Oswaldo Cruz, Brazil,

${ }^{4}$ Programa de Pós-graduação em Química, Universidade Federal Fluminense, Brazil,

${ }^{5}$ Laboratório de Produtos Naturais de Algas Marinhas, Departamento de Biologia Marinha, Instituto de Biologia Universidade Federal Fluminense, Brazil,

${ }^{6}$ Laboratório de Virologia Molecular, Departamento de Biologia Celular e Molecular, Universidade Federal Fluminense, Brazil.

\begin{abstract}
Bovine viral diarrhea virus (BVDV) is an etiologic agent that causes important economic losses in the world. It is endemic in cattle herds in most parts of the world. The purpose of this study was to evaluate the in vitro cytotoxic effect and antiviral properties of several marine natural products obtained from seaweeds: the indole alkaloid caulerpin $(\mathrm{CAV}, 1)$ and three diterpenes: 6-hydroxydichotoma3,14-diene-1,17-dial (DA, 2), 10,18-diacetoxy-8-hydroxy-2,6-dolabelladiene (DB1, 3 ) and 8,10,18-trihydroxy-2,6-dolabelladiene (DB3,4). The screening to evaluate the cytotoxicity of compounds did not show toxic effects to MDBK cells. The antiviral activity of the compounds was measured by the inhibition of the cytopathic effect on infected cells by plaque assay $(\mathrm{PA})$ and $\mathrm{EC} 50$ values were calculated for $\mathrm{CAV}(\mathrm{EC}=2,0 \pm$

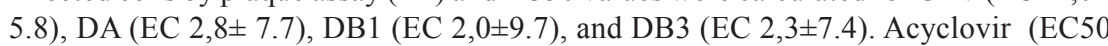
$322 \pm 5.9)$ was used in all experiments as the control standard. Although the results of the antiviral activity suggest that all compounds are promising as antiviral agents against BVDV, the Selectivity Index suggests that DB1 is the safest of the compounds tested.
\end{abstract}

Revista Brasileira de Farmacognosia Brazilian Journal of Pharmacognosy 22(4): 813-817, Jul./Aug. 2012

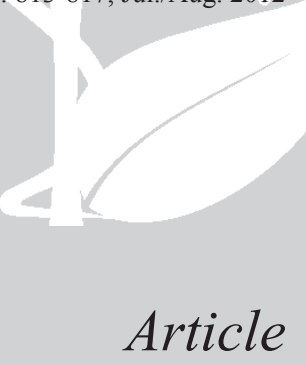

Received 4 Dec 2011
Accepted 29 Jan 2012

Available online 15 May 2012

Keywords:

BVDV

antiviral

caulerpin

diterpenes

marine algae

Caulerpa

Dictyota

ISSN 0102-695X

http://dx.doi.org/10.1590/S0102$695 \times 2012005000060$

\section{Introduction}

Bovine viral diarrhea virus (BVDV) is an important pathogen of cattle. It is endemic in cattle herds in most parts of the world. It belongs to the family Flaviviridae and is the prototype virus of the genus Pestivirus, which also includes Hog Cholera Virus (HCV) and Border Disease Virus (BDV), the etiologic agents of Classical Swine Fever and sheep fever, respectively (Paton et al., 1995).

BVDV is a small enveloped virus with a diameter of about $40 \mathrm{~nm}$, with a capsid of icosahedral symmetry that protects the genomic RNA of about $12.5 \mathrm{~kb}$ containing a positive polarity sequence 5 ' untranslated region (5'UTR) of 381-386 nucleotides (nt) that is conserved among the Pestivirus and a single large open reading frame (ORF) that encodes about 4000 amino acids and is flanked by nontranslated regions (NTR) at the 5' and 3' ends The open reading frame is translated into a single polyprotein (NH2-Npro, C, Erns, E1, E2, p7, NS2, NS3, NS4A, NS4B, NS5A, NS5B-COOH) which is co- and post-translationally processed by cellular and virus-encoded proteases, giving rise to the structural (C, Erns, E1, E2, p7) and nonstructural (Npro, NS2/3, NS4A, NS4B, NS5A and NS5B) functional viral proteins (Lindenbach \& Rice, 2000).

The BVDV have been classified as BVDV genotype 1 (BVDV1) or BVDV genotype 2 (BVDV2), based on the analysis of the 5' non-coding region (5'NCR) 
of the genome, which is considered highly conserved between Pestivirus. Viruses from either the BVDV 1 or BVDV 2 genotypes have shown characteristic phenotypes in cell culture and are classified as non-cytopathic or cytopathic biotypes (Ridpath et al., 1994). The molecular difference between the cytopathic and non-cytopathic biotypes is the production in infected cells of the cleavage product of the gene NS2/3 (p125) in NS3 (p80) and NS2 ( $\mathrm{p} 54)$, while in cells infected with non-cytopathic BVDV only p125 is detected (Donis \& Dubovi, 1987).

BVDV has been associated with significant economic loss throughout the world. Although several prevention and control measures for BVDV have been adopted, the disease remains prevalent and the key for effective control is to protect the fetus from persistent infection during the first ninety days of gestation. Bovine persistently infected by non-cytopathic BVDV are immunotolerant to the virus. They have infectious virions in all body secretions and can develop a potentially fatal form of BVDV, known as mucosal disease, resulting from the genetic recombination between non-cytopathic and cytopathic BVDV. BVDV have been involved in other clinical disorders such as abortion, teratogenesis, respiratory diseases, neurological disturbances and immune dysfunction (Salim et al., 2010). In addition, BVDV can be an important contaminant in the laboratory. They have been detected in bovine serum, several cell lines and human viral vaccines (Bolin et al., 1991).

Vaccination adopted as a method of control causes concern due to the viral characteristics of antigenic and genetic diversity (Kalaycioglu et al., 2007), so the discovery of new antiviral agent has been the aim of researchers (Tabarrini et al., 2006; Paeshuyse et al., 2007; Salim et al., 2010).

The knowledge of the events occurring during the replication cycle of BVDV is important when studying the antiviral activity of a compound. The route used by Pestivirus to enter into cells has been studied and it appears that the mechanism is by receptor-mediated endocytosis. The acidic $\mathrm{pH}$ in endosomes promotes activation of protein E, after cleavage of glycoprotein PrM that covers the fusion peptide, followed by subsequent changes that provide the energy needed for fusion and release of the viral genome into the cytoplasm (Krey et al., 2005).

The purpose of this study was to evaluate the in vitro cytotoxic effect and antiviral properties of several marine natural products, the indole alkaloid caulerpin (CAV, 1), isolated form Caulerpa racemosa (Forsskål) J. Agardh, and three diterpenes: 6-hydroxydichotoma-3,14diene-1,17-dial (DA, 2) isolated from Dictyota menstrualis (Hoyt) Schnetter, Hörnig, and Weber- Peukert; and 10,18diacetoxy-8-hydroxy-2,6-dolabelladiene (DB1, 3) and 8,10,18-trihydroxy-2,6-dolabelladiene (DB3, 4), both isolated from Dictyota pfaffii Schnetter.

\section{Materials and Methods}

Seaweeds, natural products and acyclovir (control substance)

Caulerpin (1) was isolated from the green alga Caulerpa racemosa, collected on vertical rock walls in São Pedro and São Paulo Archipelago $\left(00^{\circ} 55^{\prime} \mathrm{N}\right.$ and $\left.29021^{\prime} \mathrm{W}\right)$. Diterpene 2 was isolated from the brown alga Dictyota D. menstrualis collected at Praia Rasa,

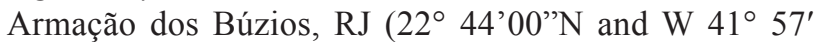
$\left.25^{\prime \prime} \mathrm{W}\right)$. Diterpenes 3 and 4 were isolated from the brown alga D. pfaffii, collected at Atol das Rocas reef, RGN (03'51'03'S and 3340'29'W). The algae were collected and identified by VLT and RCV.

Isolation, purification and structural elucidation of caulerpin (1) and the diterpenes (2-4) were performed according to the method established by Ferreira (2009) and Cavalcanti et al. (2006, 2011).

Acyclovir (ACV) was purchased from Sigma Chemical Company and used as the standard antiviral compound for all tested compounds. All compounds were dissolved in dimethylsulfoxide (DMSO, from Sigma) to obtain $50 \mathrm{mM}$ stock solutions and then diluted in culture medium without serum, to obtain the desired concentration before use. The final concentration of DMSO was $<0.1 \%$.

\section{Virus and cells}

The BVDV-1 virus and the Madin-Darbin bovine kidney (MDBK) cell lineage, originally obtained from ATCC(CCL-22) and used for virus multiplication and drug assays, were kindly provided by the virology section of the Universidade Federal de Santa Maria, RS. MDBK

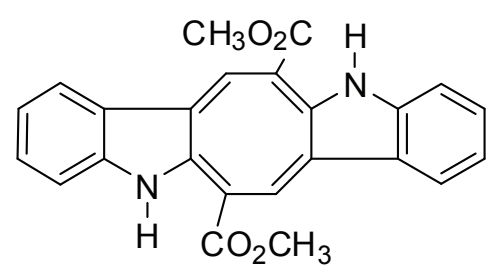

1

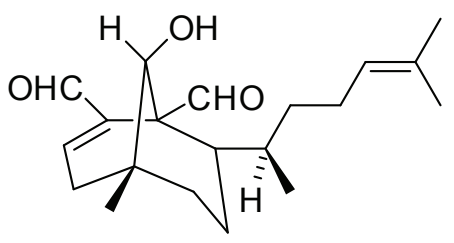

2

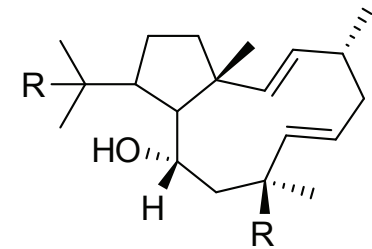

$3 \mathrm{R}=\mathrm{OAC}$ $4 \mathrm{R}=\mathrm{OH}$ 
cells were cultured in Eagle's minimal essential medium (E-MEM) containing Eagle salt, L-glutamine, and $50 \mu \mathrm{g}$ of gentamicin per $\mathrm{mL}$ and supplemented with $5 \%$ heated inactivated horse serum from Gibco Company. Overlay medium for the plaque assay consisted of E-MEM $2 \mathrm{x}$ plus $2 \%$ horse serum in agarose $2 \%(1: 1)$ and antibiotic as described above.

BVDV-1 Singer Virus stocks were propagated in MDBK cells and the virus titer was determined by plaque assay and Reed \&. Müench (1938) assay and expressed as plaque forming units (P.F.U) per $\mathrm{mL}$ and TCID50\%, respectively, and stored at $-70{ }^{\circ} \mathrm{C}$ until use.

\section{Cytotoxicity assay}

To determine the cytotoxic effect of the compounds, confluent MDBK cells were grown in 96 well plates at a density of $3 \times 10^{3}$ for $48 \mathrm{~h}$ at $37^{\circ} \mathrm{C}$ and $5 \%$ $\mathrm{CO}_{2}$. Then they were treated with varying concentrations of the test compounds $(25,50,250,500$ and $1000 \mu \mathrm{M})$ and cytotoxicity was examined by the ability of the mitochondrial enzyme succinate dehydrogenase to cleave the tetrazolium salt MTT [3-(4,5-dimethylthiazol2yl)-2,5diphenyl tetrazolium bromide; Sigma-Aldrich] (Mosmann, 1983). The resulting blue product, formazan, was further dissolved in dimethylsulfoxide (P.A) and quantified by spectrophotometry using a plate reader at 520 $\mathrm{nm}$. The cytotoxic concentration (CC50) was determined by linear regression analysis as the concentration of the compound that reduced the optical density of MTT by half in relation to the control.

\section{Antiviral plaque reduction assay (APRA)}

The inhibitory effects on plaque formation were determined as described previously (Cheng et al., 2004) with some modifications. MDBK cells at a density of $10^{4}$ were seeded in 24 well culture plates and, after $24 \mathrm{~h}$ at $37^{\circ} \mathrm{C}$ and $5 \% \mathrm{CO}_{2}$, confluent MDBK monolayers were infected with 200 P.F.U Singer. After one hour for virus adsorption period, the inoculum was discarded. Overlay medium containing different concentrations of the compounds was added and incubated for $48 \mathrm{~h}$. The cell monolayer was fixed, stained with $1 \%$ crystal violet in $10 \%$ formalin and the plaques were counted in a plaque viewer. The minimal concentration of compound required to inhibit the number of plaques by $50 \%$ (EC50) was calculated by the formula:

$$
\text { Percent of inhibition }(\%)=\frac{\text { Number of control plaques }- \text { Number of testes plaques }}{\text { Number of control plaques }} \times 100
$$

\section{Results}

Cytotoxic assay
Table 1 shows the results of the cytotoxic effects on MDBK cells treated with different concentrations $(25,50,250,500$ and $1000 \mu \mathrm{M})$ of the compounds after $48 \mathrm{~h}$, calculated by linear regression analysis. All of the results represent the mean $\pm \mathrm{SD}$ of triplicates of each experiment. In the screening assay, all concentrations of the compounds were somewhat toxic to MDBK cells, but DB1 was the safest of all (Table 1).

\section{Antiviral assay}

Results of antiviral activities (EC50) within this group of molecules show that CAV, DA-1, DB1, and DB3 are promising compounds, but DB1 was the safest of all due to the high value of SI arising from the low cytotoxicity. On the other hand, acyclovir showed only slight antiviral activity in Singer (BVDV-1) production (Table 1 and Figure 1).

Table 1. Exposure cytotoxicity, anti-BVDV-1 activity, and selectivity index (SI) of the compounds on MDBK cells.

\begin{tabular}{lccc}
\hline Compounds & $\begin{array}{c}\text { Cytotoxicity } \\
\text { CC50 }\end{array}$ & $\begin{array}{c}\text { Antiviral activity } \\
\text { EC50 }\end{array}$ & $\begin{array}{c}\text { Selective Index } \\
(\text { SI) }\end{array}$ \\
\hline CAV (1) & $1397 \pm 10$ & $2,0 \pm 5.8$ & 699 \\
DA (2) & $1303 \pm 13$ & $2,8 \pm 7.7$ & 465 \\
DB1 (3) & $3249 \pm 4.3$ & $2,0 \pm 9.7$ & 1625 \\
DB3 (4) & $2548 \pm 12$ & $2,3 \pm 7.4$ & 1108 \\
Acyclovir & $964 \pm 2$ & $322 \pm 5.9$ & 3.0 \\
\hline
\end{tabular}

a Data represent the mean \pm SD of three independent experiments; CC50 is the concentration of compound that was cytotoxic to $50 \%$ of the MDBK cells; ${ }^{b}$ Antiviral activity was assayed by the plaque reduction assay (PRA); Cell Cytotoxicity was performed by MTT after 48 h; EC50 was the antiviral concentration that was effective in inhibiting $50 \%$ of the Singer replication 'Selectivity Index (SI) is the ratio of CC50 and EC50.

\section{Discussion}

BVDV is an economically important bovine pathogen. In addition, BVDV may be related to contamination in the laboratory. It has been detected in bovine serum and in several cell lines and viral vaccines (Bolin et al., 1991). We report the inhibitory activity of caulerpin (1) and three diterpenes on BVDV-1 replication. The present results from the search for compounds with antiviral activity against BVDV also suggest that it might be relevant to evaluate antiviral activity against hepatitis $\mathrm{C}$ virus due to their similar characteristics. The mechanisms of action of the compounds studied here have not yet been determined, making it premature to speculate as to which step of the virus replication is the target for the antiviral activity of these compounds. 


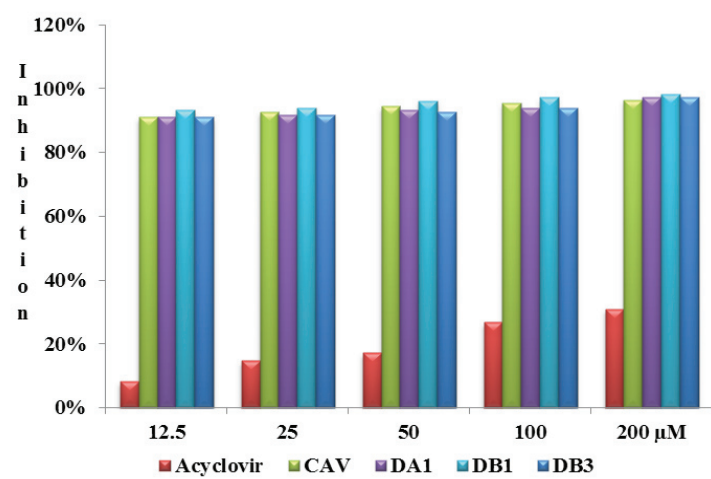

Figure 1. Comparative activity of the compounds on Singer (BVDV-1) replication. The antiviral activities of the compounds were assayed on MDBK cells grown in 24 well culture plates at a density of $2 \times 10^{4}$ for $24 \mathrm{~h}$ at $37{ }^{\circ} \mathrm{C}$ and $5 \% \mathrm{CO}_{2}$. The monolayers were then infected with 200 P.F.U of Singer. After $1 \mathrm{~h}$ for virus adsorption, the inoculum was removed and various concentrations of the compound were added and the plates reincubated under the same conditions above for an additional $48 \mathrm{~h}$. The cell monolayer was fixed and stained with $1 \%$ crystal violet in $10 \%$ formalin, the plaques were counted in a plaque viewer and the percentage inhibition was determined.

\section{Acknowledgment}

The authors thank CNPq-Universal, CAPES, FOPESQ-UFF and FAPERJ for the financial support and fellowships. We are grateful to the CNPq for productivity fellowships to ICNPP and VLT.

\section{References}

Bolin SR, Matthews PJ, Ridpath JF 1991. Methods for detection and frequency of contamination of fetal calf serum with bovine viral diarrhea virus and antibodies against Bovine Viral Diarrhea Virus. J Vet Diagn Invest 3: 199203.

Cavalcanti DN, Rezende CM, Pinto AC, Teixeira 2006. Diterpenoid constituents from the brown alga Dictyota menstrualis (Dictyotaceae, Phaeophyta). Nat Prod Comm 1: 609-611.

Cavalcanti DN, Oliveira MAR, De-Paula, JC, Barbosa LS, Fogel T, Pinto MA, Paixão ICNP, Teixeira VL. 2011. Variability of a diterpene with potential anti-HIV activity isolated from Brazilian Brown alga Dictyota menstrualis. J Appl Phycol 23: 873-876.

Cheng HY, Lin TC, Yang CM, Wang KC, Lin LT, Lin CC 2004. Putranjivain A from Euphorbia jolkini inhibits both virus entry and late stage of replication of herpes simplex virus type 2 in vitro. J Antimicrob Chemother 53: 577-583

Donis RO, Dubovi EJ. 1987. Differences in virus-induced polypeptides in cells infected by cytopathic and noncytopathic biotypes of bovine virus diarrheamucosal disease virus. Virology 158: 168-173.

Ferreira WJ 2009. Produtos Naturais de Macroalgas Marinhas - perfil químico e atividades biológicas. Niterói, Tese de Doutoramento, Programa de Pós-graduação em Química, Universidade Federal Fluminense.

Kalaycioglu TA, Russell PH, Howard CR 2007. Selection of mimotopes of Bovine Viral Diarrhoea Virus using a solid-phase peptide library. Vaccine 25: 7081-7086

Krey T, Thiel H-J, Rümenapf T 2005. Acid resistant bovine Pestivirus requires activation for $\mathrm{pH}$-triggered fusion during entry. J Virol 79: 4191-4200.

Lindenbach B, Rice CM 2001. Flaviviridae: the viruses and their replication. In: Field BN, Howley PM, Griffin DE, Lamb RA, Martin MA, Roizman B, Straus SE, Knipe DM (Eds.), Field's Virology, 4th ed. Lippincott Williams and Wilkins, Philadelphia, pp. 991-1042.

Mosmann T 1983. Rapid colorimetric assay for cellular growth and survival. J Immunol Methods 65: 55-63

Paeshuyse J, Chezal JM, Froeyen M, Leyssen P, Dutartre H, Vrancken R, Canard B, Letellier, C, Li T, Mittendorfer H, Koenen F, Kerkhofs P, De Clercq E, Herdewijn P, Puerstinger G, Gueiffier A, Chavignon O, Teulade JC, Neyts J 2007. The imidazopyrrolopyridine analogue AG110 is a novel highly selective inhibitor of pestivirus that target the RNA-dependent RNA polymerase at a hot spot for inhibition of viral replication. $J$ Virol 81 : 11046-11053.

Paton DJ, Carlssson U, Lowings JP, Sands JJ, Vilcek S, Alenius S, 1995. Identification of herd-specific bovine viral diarrhoea virus isolates from infected cattle and sheep. Vet Microbiol 43: 283-294.

Reed LJ, Müench H 1938. A simple method of estimating fifty per cent endpoints. Am J Hyg 27: 493-497.

Ridpath JF, Bolin SR, Dubovi EJ. 1994. Segregation of bovine viral diarrhea virus into genotypes. Virology 205: 6674.

Salim MTA, Goto Y, Hamasaki T, Okamoto M, Aoyama H, Hashimoto Y, Musiu S, Paeshuyse J, Neyts J, Froeyen M, Herdewijn P, Baba M 2010. Highly potent and selective inhibition of bovine viral diarrhea a virus replication by y-carboline derivatives. Antiviral Res 88: 263-268.

Salim MTA, Okamoto M, Hosada S, Aoyama H, Hashimoto Y, Baba M 2010. Anti-bovine viral diarrhoea virus activity of novel diphenylmethane derivatives. Antiviral Chem Chemother 20: 193-200.

Tabarrini O, Manfroni G, Fravolini A, Cecchetti V, Sabatini S, De Clercq E, Rozenski J, Canard B, Dutartre H, Paeshuyse J, Neyts J 2006. Synthesis and anti-BVDV activity of acridones as new potential antiviral agents. $J$ Med Apr 49: 2621-2627. 


\section{*Correspondence}

Izabel Christina Nunes de Palmer Paixão

Laboratório de Virologia Molecular, Programa de Pósgraduação em Biologia das Interações, Departamento de Biologia Celular e Molecular, Instituto de Biologia Universidade Federal Fluminense

Outeiro São João Batista s/n, Valonguinho, Niterói-RJ, Brazil

ipaixao@vm.uff.br

Tel.: +552126292280 